\title{
EFEKTIFITAS STRATEGI PEMASARAN PRODUK WISATA MINAT KHUSUS GUA CERME, IMOGIRI, BANTUL
}

\author{
Cahya Purnomo \\ Akademi Maratim Yogyakarta \\ e-mail: cahyapiyungan@yahoo.com
}

\begin{abstract}
This research is aimed to recognize the marketing strategy for special interest tourism product of Cerme Cave located in Imogiri Subdistrict, Bantul Regency. The method used in this research is a descriptive survey method. Purposive sampling is used to determine sample. Findings found that the market characteristics of the respondens are young men, well educated, like to do adventure people, unemployment, group visitors; spend less expenditure and local people. Their main activities are tracing along the cave and doing the relaxation. The marketing strategy is recommended with $7 P$.
\end{abstract}

Keyword: karakteristik pasar, kualitas produk, strategi marketing, stakeholders, gua cerme, Bantul

\section{PENDAHULUAN}

Pembangunan sektor pariwisata dimaksudkan dapat meningkatkan pertumbuhan ekonomi, meningkatkan kesejahteraan rakyat, menghapus kemiskinan, dan mengatasi pengangguran. Pembangunan pariwisata yang bermuara kepada tujuan tersebut, pada dasarnya tidak terlepas dari peran serta masyarakat dan pemerintah daerah sebagai regulator. Peran tersebut dapat dimplementasikan ke dalam berbagai bentuk usaha-pelayanan jasa pariwisata.

Kontribusi industri pariwisata bagi produk domestik bruto (PDB) Indonesia cukup signifikan, yakni 11,03 persen. Pencapaian devisa dari sektor ini pada 2007 sebesar US\$ 5.345,98 juta (http://www.budpar.go.id). Menurut Pitana (2005), pariwisata sebagai industri terbesar kedua di dunia setelah migas mampu menjadi primadona penghasil devisa negara. Oleh karenanya pemerintah sewajarnya mulai menggalakkan program pembangunan pariwisata di berbagai daerah sekaligus menempatkannya sebagai pendekatan pembangunan alternatif.

Kabupaten Bantul yang memiliki potensi Obyek dan Daya Tarik Wisata (ODTW) alam dan budaya dan beragam perlu dikemas dan dipasarkan dengan efektif. Pemasaran dengan peningkatan daya tarik dan informasi wisata, sosialisasi program, promosi ke luar daerah, pelestarian keunikan-kekhasan, delivery of service, kenyamanan dan kecepatan pelayanan merupakan tuntutan pemasaran yang berkelanjutan.

Sekarang ini hampir di tiap daerah yang memiliki ODTW telah mengembangkan potensinya untuk menarik wisatawan. Implikasi dari kondisi ini adalah menimbulkan persaingan antar daerah yang ingin mengunggulkan obyek wisata di daerahnya masing-masing. Oleh karenanya tiap daerah dituntut untuk bisa mengembangkan produk wisata yang bervariasi dan unik.

Berangkat dari latar belakang di atas maka permasalahan dalam penelitian ini adalah "bagaimana strategi pemasaran 
produk wisata minat khusus Gua Cerme yang efektif?" dan "apa kendalanya?"

Tujuan spesifik yang ingin dicapai dari penelitian ini: (1) untuk mengetahui strategi pemasaran produk wisata minat khusus Gua Cerme yang efektif dan (2) untuk mengetahui kendala penerapan strategi pemasaran tersebut, sehingga diketahui solusinya. Sedangkan manfaatnya adalah: (1) sebagai masukan bagi Pemerintah Kabupaten Bantul dalam mengambil kebijakan pemasaran produk wisata minat khusus Gua Cerme, dan (2) memberikan informasi kepada stakeholder pariwisata untuk kepentingan usaha-pelayanan pariwisata.

\section{TINJAUAN PUSTAKA \\ Kebutuhan Manusia dan Kebutuhan Berwisata}

Secara kodrati manusia mempunyai kebutuhan yang harus dipenuhi untuk keberlanjutan hidupnya. Kotler (1993) berpendapat bahwa kebutuhan manusia adalah suatu keadaan yang dirasakan ketiadaan kepuasan dasar tertentu, misalnya kebutuhan pangan dan sandang. Kebutuhan tersebut tidak diciptakan namun sudah melekat pada diri manusia. Sedangkan keinginan adalah kehendak yang kuat akan pemuas yang spesifik terhadap kebutuhan. Kemudian permintaan adalah keinginan akan produk yang spesifik yang didukung dengan kemampuan untuk membelinya (Kotler, 1993)

Menurut Mill and Morison (1985), kegiatan hidup manusia terbagi dalam tiga kegiatan utama. Pertama, kegiatan bekerja untuk memperoleh pendapatan, kedua kegiatan maintenance untuk pemulihan (misalnya makan, minum, tidur) dan ketiga adalah kegiatan leisure (Kegiatan leisure adalah kegiatan pemanfaatan waktu luang, yang dapat diwujudkan dalam bentuk berwisata. Berwisata pada prinsipnya adalah perpindahan tempat sementara atau perjalanan ke lain tempat dari tempat tinggalnya (Gartner,1996). Kebutuhan akan per- jalanan ke lain tempat sudah dilakukan manusia sejak lama. Dengan demikian berwisata merupakan kebutuhan manusia yang penting sebagaimana kebutuhan lainnya. Terlebih pada jaman modern di mana tuntutan hidup semakin berat sehingga orang lebih mudah terkena depresi.

Menurut Wahab (1992), pariwisata sebagai fenomena masyarakat modern. Di sisi lain dengan peningkatan status sosial ekonomi akan berpengaruh terhadap kebutuhan berwisata. Semakin tinggi kesejahteraan ekonomi seseorang semakin banyak dan meningkat kebutuhan berwisatanya (Hermansyah, 2007). Motivasi berwisata seseorang digolongkan menjadi: physical motivation, cultural motivation, social motivation dan fantasy motivation (Pitana, 2005).

\section{Pariwisata Sebagai Produk Jasa}

Produk pariwisata adalah berupa jasa atau layanan. Konsumen akan mengkonsumsi produk ini dengan memperoleh pengalaman dari perjalanan yang dilakukannya. Sifat dasar produk pariwisata adalah intangibility, heterogenity, perishability, inseparability (Holloway \& Robinson, 1995). Di samping itu produk wisata tak bisa dipisahkan satu dengan lainnya, tidak bisa distandardisir seperti barang, karena merupakan produk dari banyak elemen. Zeithaml dan Bitner (1996), memaknai produk jasa mencakup semua aktivitas ekonomi yang produk dan konsumnya dilakukan pada waktu yang sama, nilai tambah yang diberikannya dalam bentuk kenyamanan, liburan, kecepatan, kesehatan.

Menurut Fandeli (2002), produk pariwisata adalah sesuatu yang dapat ditawarkan kepada pasar agar orang tertarik perhatiannya, ingin memiliki, memanfaatkan dan mengkonsumsinya untuk mendapatkan kepuasan. Produk pariwisata itu termasuk obyek fisik, pelayanan, tempat, organisasi. Ada empat level yang melekat pada produk 
pariwisata: produk inti, fasilitas, penunjang serta produk tambahan. Sedangkan menurut Yoeti (1997), produk wisata terdiri dari unsur $3 \mathrm{~A}$ : atraksi, amenitas dan aksesibilitas. Dari ketiga unsur itu yang dominan adalah atraksi, tanpa atraksi tidak ada kegiatan pariwisata. Atraksi harus ada syarat : (1) apa yang bisa dilihat (2) apa yang bisa dilakukan dan (3) apa yang bisa dibeli.

\section{Pariwisata Minat Khusus Penelusuran Gua}

Bahwa sejak tahun 1990-an pasar wisatawan telah mengalami pergeseran, dari wisatawan masif ke wisatawan yang lebih individual. Dinamika perubahan dunia pada berbagai aspek kehidupan ternyata telah membawa perubahan terhadap selera dan pola konsumsi berwisata Damanik (2007). Bahkan daerah pinggiran yang buruk, justru menarik sebagai obyek keingintahuan (Azarya, 2004). Fenomena global tersebut dalam kepariwisataan diikuti dengan munculnya wisata minat khusus, yang oleh de Kadt (1992) disebut wisata alternatif.

Wisata minat khusus adalah bentuk perjalanan wisata, di mana wisatawan mengunjungi suatu tempat karena memiliki minat khusus dari obyek atau kegiatan di daerah tujuan wisata (Weiler and Hall, 1992). Pariwisata minat khusus pelakunya cenderung untuk memperluas pencariannya yang berbeda dengan mengamati orang, budaya, pemandangan, kegiatan kehidupan sehari-hari, nilai-nilai akrap lingkungan. Bentuk kegiatan maupun pengalaman yang diharapkan sangat beragam, sebagaimana pernyataan Weiler and Hall (1992): "The special interest traveller wants to experience something new, wheither it is history, food, sport, custo or the outdoor. Many wish to appreciate the new sight, sound, smells, tastes and to understand the place and its people”.

Salah satu bentuk kegiatan pariwisata adalah petualangan, seperti penelusuran gua (Fandeli, 2002). Aktivitas petualangan penelusuran gua banyak mengeluarkan tenaga dan mengandung unsur tantangan, oleh karenanya diperlukan keberanian. Prinsip pengembangan wisata jenis ini didasarkan pada motivasi perjalanan : (1) pencarian sesuatu yang unik atau novelty seeking (2) pencarian pengalaman berkualitas atau quality seeking (3) penghargaan atas sesuatu obyek atau rewarding (4) pengkayaan pengetahuan terhadap sesuatu kegiatan atau enriching (5) pelibatan dalam petualangan atau adventuring dan (6) proses belajar terhadap kegiatan yang diikuti atau learning (Weiler and Hall, 1992).

Kegiatan penelusuran gua sekarang telah menjadi kegiatan wisata minat khusus dengan gua-gua kars sebagai lahan penelusuran. Gua adalah setiap ruangan di bawah tanah yang dapat dimasuki orang (Sujali,1989). Gua merupakan sistim, di mana gua yang satu dengan yang lain berhubungan. Daya tarik wisata gua kars adalah terletak pada bentuk, jenis dan persebaran obyek pada gua itu. Sedangkan menurut MAPALA GEGAMA Fak. Geografi UGM (2008), salah satu daya tariknya adalah karena mempunyai daya tarik fisik (speleotherm), pemandangan di luar maupun daya tarik mistisnya.

\section{Pemasaran Pariwisata}

Dalam pariwisata, dikenal destinasi sebagai tujuan wisata, merupakan bagian dari produk pariwisata. Dengan demikian pemasaran pariwisata merupakan proses strategis memasarkan sumberdaya pariwisata berupa destinasi atau obyek wisata. Hal ini diperkuat pendapat Holloway and Robinson (1995) sebagai berikut: "marketing is a strategic process that aims to fit the resources of a destination to the opportunities existing in the market. It is as much about retaining tourists as it is about winning new business". Sebagai jasa, untuk dapat memasarkan pariwisata perlu didukung dengan fasilitas atau bukti fisik 
(Yazid, 1999). Pemasaran pariwisata tidak cukup hanya meliputi 3 A saja, namun lebih jauh lagi, siapa sebetulnya segmen pasarnya dan bagaimana perilakunya (Damanik, 2006), Penekanannya bagaimana mengkomunikasikan kepada pasar bahwa produk yang ditawarkan (destinasi) adalah unggul dan berbeda dengan produk lain. Media promosi konvensional tidak selamanya dapat digunakan untuk produk pariwisata, terlebih produk wisata minat khusus. Pemasaran pariwisata menurut Holloway and Robinson (1995), terdiri dari $7 \mathrm{P}$, yaitu product, positioning, price, promotion, place, packaging, partnership

\section{METODOLOGI PENELITIAN}

Penelitian ini menggunakan metode survai, bersifat diskriptif, yang tujuannya adalah untuk membuat diskripsi secara sistematis mengenai fakta-fakta serta hubungan antara fenomena yang diteliti (Natzir, 1983) dengan mengambil lokasi obyek wisata Gua Cerme, Kecamatan Imogiri Kabupaten Bantul. Populasi adalah jumlah pengunjung Gua Cerme selama tahun 2008 yaitu sebanyak 13.800 orang, kemudian sampel ditentukan dengan metoda purposive sampling, (Kusmayadi dan Sugiarto, 2000) sebanyak 139 orang. Pengumpulan data primer yang menyangkut profil dan karakteristik pasar ditempuh dengan kuesioner, sedangkan data sekunder tentang produk dengan dokumentasi. Wawancara ditempuh untuk memperkuat data dari kuesioner. Kemudian observasi digunakan untuk mendapatkan informasi riil kondisi obyek wisata dan kegiatan pengunjung yang dilakukan di obyek.

Analisis karakteristik pasar dengan distribusi frekuensi, yang berisi karakteristik sosial-demografi dan psikografi pasar. Sedangkan produk dianalisis dengan zonasi kawasan dan skoring mutu produk wisata. Skoring mutu produk wisata berdasarkan Buerau of Land Management (Manessa, 2008) dan Akhmadi (2003) yang dikompilasikan dengan Direktorat Wisata Alam dan Pemanfaatan Jasa Lingkungan Departemen Kehutanan (2001)

Skoring atraksi diukur dengan 9 variabel dan sub variabel. Rentang skor terendah 13 dan skor tertinggi 43. Interval 30 dibagi ke dalam tiga kelas, 13 - 23: potensi rendah, 23 - 33: potensi sedang, dan $34-43$ : potensi tinggi. Skoring aksesibilitas diukur dengan 3 variabel. Rentang skor terendah 3 dan skor tertinggi 9. Interval 6 dibagi ke dalam tiga kelas, 3 - 5: potensi rendah, 6 8: potensi sedang dan 9: potensi tinggi. Skoring fasilitas penunjang diukur dengan 4 variabel. Skor terendah 4 dan skor tertinggi 12, interval 8 dibagi ke dalam tiga kelas, $4-$ 6: potensi rendah, $7-9$ potensi sedang, dan 10 - 12: potensi tinggi.

\section{HASIL DAN PEMBAHASAN Strategi Pengembangan Produk}

Obyek wisata gua jenis obyek wisata alam, sehingga pengembangannya tetap bertumpu pada ciri khas alami in situ, hanya dapat dinikmati di tempatnya saja. Kepuasan wisatawan diperoleh dari seluruh perjalanannya dari asal tempat tinggalnya hingga kembali, merupakan total pengalaman yang harus dinikmati dan dihargai tanpa mengecewakan. Pengembangan produk sangat ditentukan oleh semua stakeholder terkait, dilaksanakan secara terpadu. Hal ini sesuai pendapat Mill and Morison (1985), bahwa pariwisata sebagai suatu sistim. Produk wisata ini menghendaki orisinalitas, otentisitas dan apa adanya karena mempunyai sifat non recoverable (Fandeli, 2002).

Kebijakan diferensiasi produk yang bisa ditempuh adalah dengan meyakinkan pada wisatawan bahwa Gua Cerme berbeda dengan obyek wisata gua-gua yang lain. Pemandangan dalam gua, panjang gua, tipe lorong, air bawah tanah serta pemandangan di luarnya adalah trademark yang perlu dipertahankan. Pencitraan bahwa Gua 
Cerme sebagai tempat bersemedi tetap harus dipertahankan untuk membedakan dengan obyek gua lain.

Kebijakan diversifikasi produk dengan mengaktifkan kembali kesenian lokal yang selama ini pasif. Atraksi utama yang ada selama ini hanya sebatas menelusur gua saja, sehingga belum ada atraksi pendukung. Kesenian lokal karawitan, solawatan, laras madya, ketoprak, srandul, dhadhungawuk layak dijadikan atraksi pendukung. Keterbatasan atraksi berimplikasi pada lama tinggal dan belanja pengunjung kecil. Dengan atraksi pendukung maka tekanan terhadap gua akan berkurang karena terjadi penyebaran pengunjung dan dampak ekonomi akan lebih baik.

Nilai mutu atraksi diperoleh hasil 38 (kategori bermutu tinggi), kemudian nilai mutu aksesibilitas 6 (kategori bermutu sedang), dan nilai mutu fasilitas 6 (kategori bermutu rendah). Nilai sedang pada aksesibilitas mengindikasikan bahwa akses pencapaian masih bisa ditingkatkan. Kermudian nilai rendah pada fasilitas mengindikasikan perlunya penambahan fasilitas penunjang.

\section{Positioning Produk}

Untuk menentukan posisi produk sudah didukung dengan kondisi gua itu sendiri, bahwa setiap gua mempunyai karakteristik sendiri-sendiri (Manesaa, 2008). Dengan demikian maka akan lebih mudah menenpatkan posisinya terhadap posisi produk wisata gua lainnya. Untuk Gua Cerme, segmen pasar yang dibidik adalah wisatawan minat khusus, terpelajar dan ingin mencari pengalaman bermutu dalam perjalanan, yang menurut Plog (1991), disebut wisatawan berkarakter allocentric. Strateginya adalah posisi mutu tinggi, menetapkan harga tinggi, promosi dengan media yang berkelas juga. Citra mutu tinggi yang konsisten dapat dipercaya, merupakan strategi melawan produk lain (Damanik, 2006).

\section{Strategi Packaging}

Pengemasan produk berperan penting dalam membentuk citra positif suatu obyek wisata. Suatu produk wisata yang inti materinya berkualitas baik namun jika dikemas seadanya akan menurunkan citra produk. Pengemasan di sini merupakan paket wisata yang ditawarkan. Dalam paket wisata halhal yang harus ada adalah: (1) rencana perjalanan harus sesuai dengan tour itinerary yang telah disusun, (2) selama perjalanan tidak ada gangguan mulai dari berangkat sampai kembali, (3) selama perjalanan ditemani tour leader yang dapat dipercaya.

Paket yang ditawarkan hendaknya dapat merangkai dengan kegiatan lain, sehingga perjalanan wisata merupakan rangkaian alur kegiatan. Berikut adalah gambar paket perjalanan.

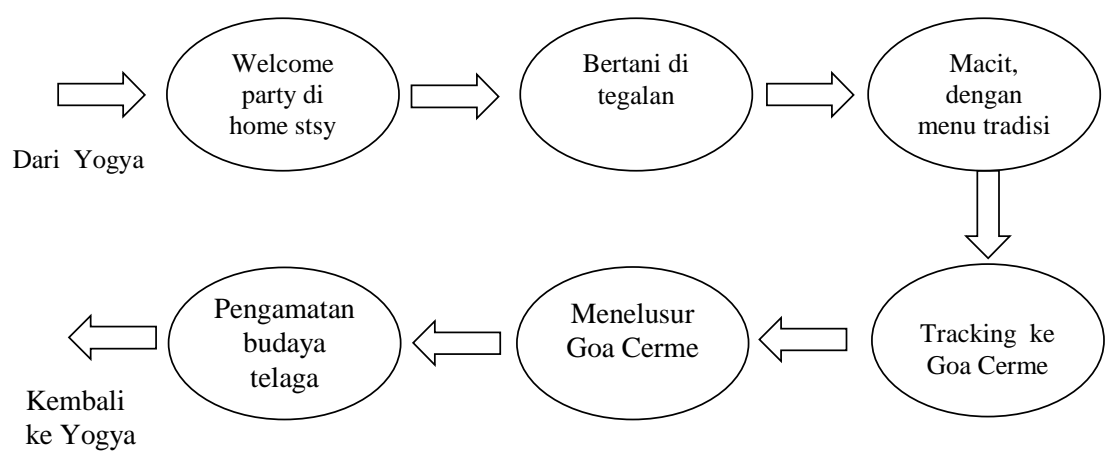

Gambar: 2. Paket Perjalanan 
Agar tidak membosankan dan dapat menimbulkan tantangan maka atraksi dikemas dengan tingkatan kesulitan yang semakin berat (klimaks). Kemasan produk wisata baru bisa dijual kalau ada aksesibilitas, yang terdiri atas prasarana jalan, sarana transportasi dan akses komunikasi yang bisa menjangkau ke suatu obyek. Untuk menikmati atraksi perlu akomodasi pendukung mulai penginapan, MCK, rumah makan dan lainnya.

\section{Kebijakan Pricing}

Penentuan harga di sini dimaksudkan sebagai sejumlah uang yang harus dipersiapkan oleh calon wisatawan untuk memperoleh jasa pariwisata yang diinginkan. Jumlah uang yang harus dikeluarkan tersebut tergantung pada: (1) tingkat kebutuhan dan keinginan yang diinginkan, (2) kondisi perekonomian pada saat wisatawan melakukan perjalanan dan (3) kapasitas wisatawan.

Wisatawan yang mempunyai kapasitas beli yang lebih tinggi umumnya dari wisatawan yang berkarakter allocentric sedangkan wisatawan yang daya belinya rendah termasuk wisatawan berkarakter psychocentric (Plog, 1991). Jika yang dibidik adalah wisatawan yang berkarakter allocentric, maka kebijakan ditempuh dengan harga premium, penetapan harga jual di atas harga pesaingnya. Bagi wisatawan ini, harga jual tidak dipermasalahkan asalkan produknya betul-betul berkualitas. sehingga dapat memberikan pengalaman perjalanan yang berkualitas pula. Yang perlu dihindarkan adalah perbedaan antara published price, yaitu harga yang dicantumkan dalam brosur dengan actual price, yaitu harga yang sebenarnya harus dibayar wisatawan.

\section{Kebijakan Distribusi}

Distribusi atau place merupakan salah satu unsur bauran pemasaran adalah tempat di mana konsumen dapat mencari informasi, memperoleh penjelasan, atau melakukan pembelian produk wisata yang ditawarkan. Singkatnya bagaimana produk wisata didistribusikan dan di-delivery dengan mudah ke konsumen. Bagian produk wisata yang secara fisik bisa di-delivery hanya cinderamata, selebihnya adalah berupa jasa, sehingga bentuk delivery-nya adalah konsumenlah yang harus datang ke produk wisata.

Sistem distribusi produk pariwisata lebih sulit dari pada industri barang. Industri pariwisata memerlukan perantara yang berfungsi menjembatani antara produsen dan konsumen (Mill and Morrison, 1985), sistim distribusi tidak langsung. Perhatikan sistem distribusi produk pariwisata tidak langsung pada Gambar 2.

Fungsi agen di sini akan mencarikan seat pada perusahan transportasi, mencarikan room pada hotel/akomodasi. Berikutnya wisatawan juga memerlukan makan minum yang dapat dicarikan pada restoran tertentu dan mencarikan pertunjukan yang diinginkan pada perusahan entertaintment. Untuk menikmati atraksi wisata baik sekedar melihat maupun aktif di dalamnya wisatawan perlu dukungan berbagai keperluan yang dapat dicarikan di shopping center. Semua itu akan lebih praktis dan efisien jika ditangani agen travel. 


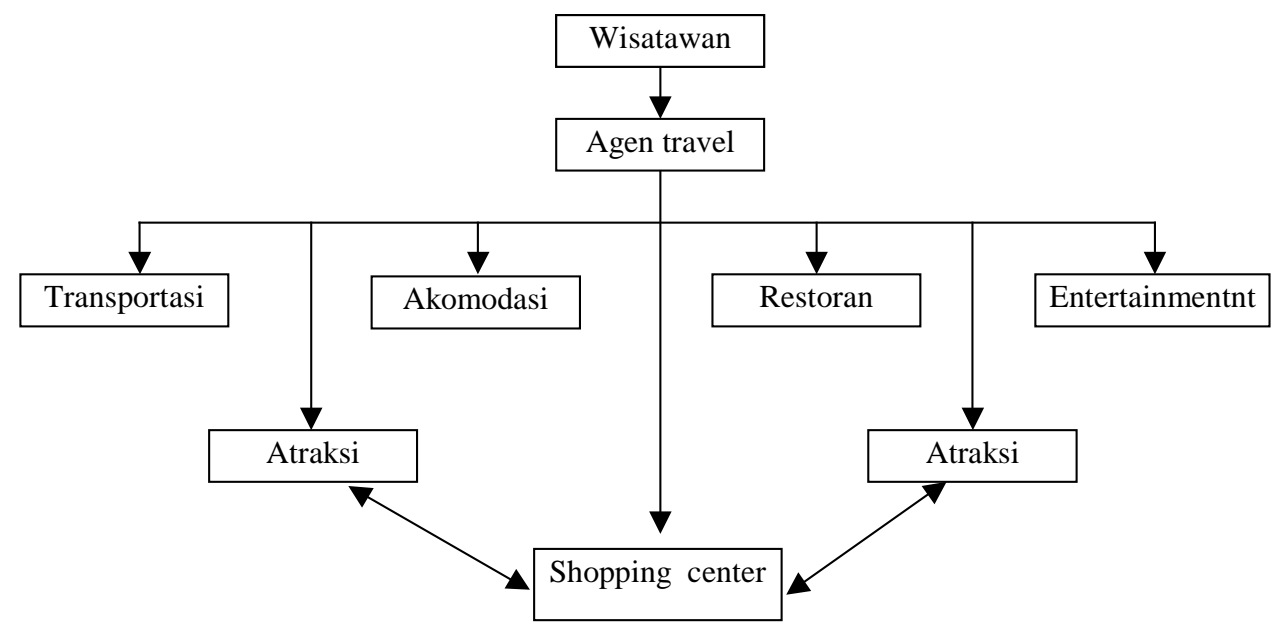

Gambar 2: Distribusi Produk Pariwisata Tidak Langsung (Sumber : Yoeti, 2003 dengan penyesuaian)

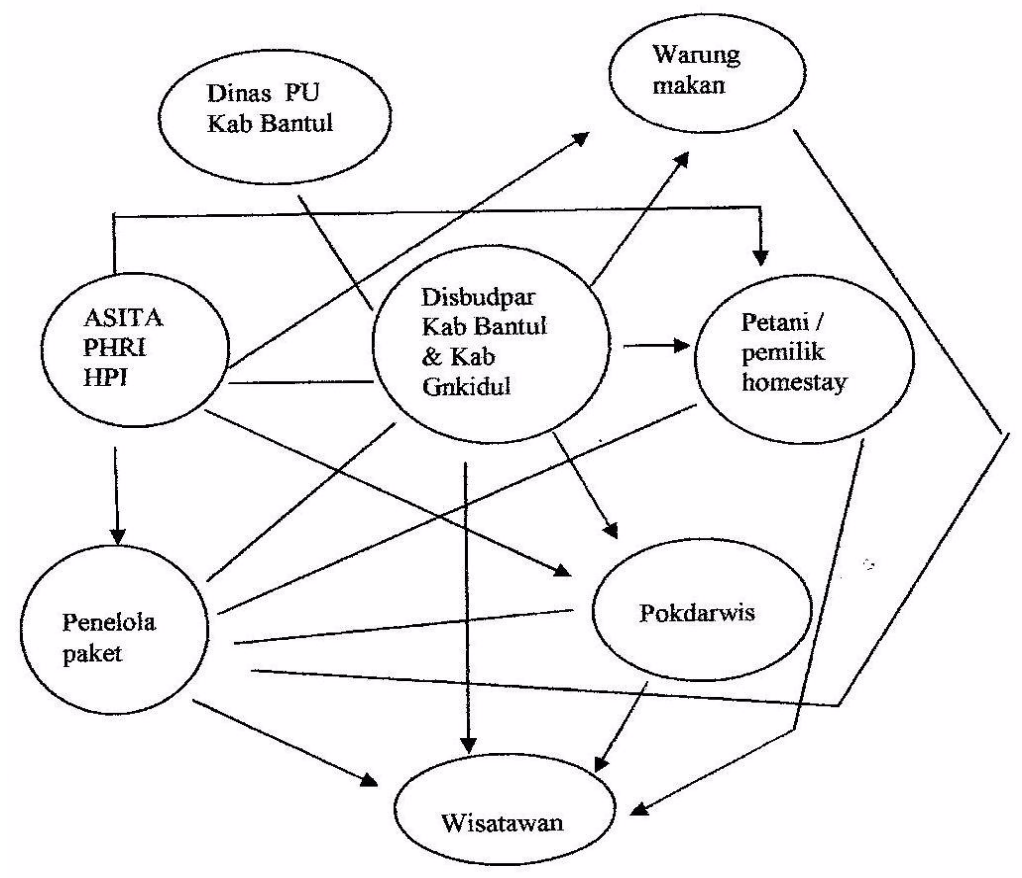

Keterangan :

$\longrightarrow$ adalah fungsi pelayanan adalah fungsi koordinasi

Gambar 3. Diagram Jejaring Kemitraan 


\section{Partnership}

Kepariwisatan merupakan sistem, sektor yang melibatkan banyak stakeholder. Salah satu stakeholder yang berperan penting di sini adalah agen travel atau biro perjalanan. Agen travel di sini merupakan mitra dari Kabupaten Bantul dalam memasarkan produknya. Menjual produk wisata ibarat menjual barang-barang mewah, sehingga citra positif harus terbangun pada benak konsumen. Pada dasarnya agen travel tidak memiliki produk sendiri, sehingga fungsinya sebagai perantara antara pemilik produk dengan konsumen.

Selain dengan agen tarvel, Kabupaten Bantul sebagai pemilik produk juga perlu menjalin kerjasama dengan kota atau bahkan negara lain untuk memasarkan produknya. Pariwisata di Bantul juga masih perlu investasi yang tidak sedikit untuk mengembangkan prasarana dan sarana penunjang. Untuk itu perlu kerja sama dengan perusahaan kuat sebagai sponsor investasi. Karena posisi Gua Cerme terletak di wilayah Kabupaten Bantul dan wilayah Kabupaten Gunungkidul, maka sudah semestinya menjalin kemitraan dengan Dinas Kabupaten Gunungkidul. Selengkapnya jejaring kemitraan tersebut dapat dilihat pada gambar 3 .

\section{Kebijakan Promosi}

Perlu diingat bahwa produk pariwisata minat khusus lebih bersifat product driven dari pada merket driven. Hal ini mengingat gua rentan rusak terhadap tekanan jumlah wisatawan. Untuk memulihkannya jika terjadi kerusakan diperlukan waktu beratus bahkan beribu-ribu tahun. Kalaupun terjadi proses pemulihan niscaya tidakakan seperti bentuk semula, karena sifatnya yang non recoverable (Fandeli, 2002). Di sisi lain pasar telah mengalami pergeseran selera berwisata dengan sebutan wisatawan minat khusus. Pemahaman karakteristik pasar yang demikian berimplikasi pada pemilihan modus promosi yang jitu.
Media iklan bisa ditempuh, asalkan pesan yang disampaikan jelas. Jika maksudnya memberitahukan, apa yang diberitahukan. Jika ingin mengajak wisatawan berkunjung bagaimana agar persuasif. Jika ingin memperingatkan bagaimana mengemasnya agar produk wisata terekam di ingatan calon wisatawan. Untuk membidik segmen pasar yang allocentric, iklan persuasif dan terkesan halus kurang tepat, karena berkarakter mereka suka tantangan. Iklan diarahkan yang dapat "memprovokasi" pengalaman berwisata mereka. Misalnya, "buktikan keberanianmu di Gua Cerme".

Segmen pasar yang lebih khusus dari golongan terpelajar dan berpendidikan tinggi perlu dirinci lagi berdasarkan interest pribadi. Pengunjung Gua Cerme mungkin geolog, biolog atau antropolog. Oleh karenanya dipilih taktik jitu, misalnya efek perubahan ekologi terhadap proses pembentukan batuan dalam gua, terhadap perilaku satwa gua, kearifan lokal dalam mengkonservasi gua. Informasi seperti ini lebih menggugah minat mereka. Strategi promosi yang efektif adalah mendekatkan mereka dengan isu-isu yang terkait dengan interest pribadi atau keahliannya. Media yang dipakai sebaiknya tidak "diobral" sebagaimana produk wisata masif, namun media yang efektif adalah melalui guru sekolah, serta melalui internet.

\section{Kendala yang Dihadapi}

Di balik strategi pemasaran sebagaimana analisis di atas terdapat kendalakendala yang dapat mengganngu efektifitasnya, yaitu:

1. Rendahnya kapasitas masyarakat sekitar obyek, yang disebabkan rendahnya pendidikan mereka. Implikasinya adalah kemampuan menemukenali potensi dan keunggulan produk sangat terbatas. Hal ini juga diikuti dengan rendahnya persepsi terhadap nilai wisata gua yang didasarkan pada nilai konservasi serta 
rendahnya kemampuan pemandu dalam menjelaskan obyek.

2. Keterlibatan masyarakat dalam program pemasaran masih rendah. Selama ini program-program pemasaran masih topdown dari Dinas Pariwisata Kabupaten Bantul, padahal seharusnya sebagaimana sifat produk wisata yang komplek harus menyertakan peran masyarakat lokal.

3. Fasilitas sebagai obyek wisata minat khusus belum memadai, baik jumlah maupun kualitas, termasuk narasi obyek, papan penunjuk, peringatan jalan, tempat ganti pakaian dan fasilitas kebutuhan makan. Akses jalan menuju obyek nampak tidak terawat.

4. Atraksi utama baru sebatas menelusur gua saja, pada hal masih bamyak atraksi yang dapat dikembangkan sehingga menambah length of stay.

5. Kebijakan harga masih mengesankan sebagai produk murahan, karena tiket masuk hanya sebesar Rp 2.250. Seharusnya justru dipasang tiket mahal, namun harus diimbangi dengan pelayanan berkualitas.

\section{KESIMPULAN DAN SARAN Kesimpulan}

Karakteristik pasar wisata khusus dengan produk kunjungan ke gua adalah berumur muda, terpelajar, motif utama kegiatan petualangan, pengeluaran masih sedikit karena umumnya pelajar belum bekerja, datang secara berombongan. Jumlah wisatawan masih jauh dari kapasitas efektif. Mereka menginginkan perjalanan berkualitas, mencari sesuatu yang baru dan dapat memperluas pengalaman.

Produk wisata yang bisa dikemas sesuai potensi adalah atraksi bertani di lahan kering, penelusuran gua dan pengamatan budaya telaga. Kemasan produk disertai itinerary, yang berisi kegiatan, waktu dan biayanya. Skor atraksi termasuk kategori tinggi. Artinya produk mempunyai mutu unggul. Skor aksesibilitas termasuk sedang. Artinya masih perlu peningkatan. Sedangkan skor fasilitas masih termasuk rendah. Artinya masih banyak yang harus diadakan. Kebijakan differensiasi produk yang bisa ditempuh adalah dengan meyakinkan pada wisatawan bahwa Gua Cerme berbeda dengan obyek wisata gua-gua yang lain, sehingga diperlukan membangun citra positif produk. Kebijakan diversifikasi produk yang bisa ditempuh adalah dengan mengaktifkan kembali kesenian lokal yang selama ini pasif.

Kebijakan partnership adalah dengan mengajak semua stakeholder untuk berperan. Unsur-unsur stakeholder tersebut adalah: Disbudpar Kab. Bantul dan Disbudpar Kab. Gungunkidul, Dinas PU. Kab Bantul, petani / pemilik homestay, pengelola paket, POKDARWIS, warung makan, ASITA, PHRI, Himpunan Pramuwisata Indonesia (HPI), dan wisatawan.

Kebijakan distribusi produk dilakukan secara tidak langsung dengan melibatkan agen perjalanan dan hotel, mengingat agen perjalanan dan hotel inilah yang tiap hari menangani wisatawan. Kemudian melibatkan sekolah dan perguruan tinggi karena pasar produk wisata ini memang kaum terpelajar.

Strategi promosi yang tepat adalah dengan "memprovokasi" calon wisatawan, mengingat pasarnya adalah berjiwa petualang dan interest terhadap kedalaman produk. Sedangkan media yang efektif adalah guru sekolah serta internet.

\section{Saran}

Peningkatan pendidikan dalam rangka pemberdayaan masyarakat sekitar obyek untuk mempertajam kemampuan menemukenali sumberdaya wisata yang dimiliki dan meningkatkan pelayanan kepada wisatawan. Peningkatan kapasitas mereka akan bermuara pada peningkatan kesejahteraan dan persepsi positif terhadap produk pariwisata. 
Promosi hendaknya tidak "diobral" mengingat pasarnya adalah wisatawan minat khusus. Peningkatan fasilitas MCK, tempat ganti pakaian, warung makan, alat penelusuran gua yang memadai, petunjuk jalan dan jarak, rambu-rambu jalan, narasi yang menginformasikan tentang obyek bertani di lahan tegalan, atraksi penelusuran gua dan atraksi budaya telaga. Semua fasilitas tersebut untuk memaksimalkan kepuasan pasar.

\section{DAFTAR PUSTAKA}

Anonymous (2008). Speleologi dan Penelusuran Gua, Materi Dasar Kepecintaalaman, Mapala GAGAMA, Fak. Geografi UGM, Yogyakarta

Anonymous (2001). Petunjuk Teknis Kriteria Penilaian dan Pengembangan Obyek Wisata Alam, Seri Wisata Alam, Direktorat Wisata Alam dan Pemanfaatan Jasa Lingkungan.

Akhmadi (2003). Penentuan Jalur Pemanduan Ekowisata di Sekitar Kawasan Wisata Gua Seplawan Kabupaten Purworejo Jawa Tengah, Skripsi. Yogyakarta: Fakultas Kehutanan UGM.

Azarya, V. (2004). Globalisation and International Tourism in Developing Countries. London: Sage Publication.

Damanik, J. (2007). Strategi Promosi Menghadapi Krisis Pariwisata dan Pergeseran Psikografi Wisatawan. Jurnal Pariwisata, Bandung: STIEPAR YAPARI - AKTRIPA,Vol. 8, No. 1.

Damanik, J. (2006). Perencanaan Ekowisata-dari Teori ke Aplikasi. Yogayakarta: Penerbit Andi.

De Kadt, E. (1992). Making the Alternative Sustainable, Lesson from Development for Tourism, Tourism Alternative, Potential and Problem in the Development of Tourism. Philladelphia: University of Pensylvania Press.
Fandeli, C. (2002). Perencanan Kepariwisatan Alam. Yogyakarta: Fak. Kehutanan UGM.

Gartner, W.C. (1996). Tourism Development-Principles, Procesess and Policies. New York: Van Nostrand Reinhold.

Hermansyah (2007). Analisis Psikografi Wisatawan Dalam Keputusan Memilih Obyek dan Daya Tarik Wisata Gunung Dempo di Kota Pagar Alam. Yogyakarta: Prodi Kajian Pariwisata Sekolah Pasca Sarjana UGM.

Holloway, JC \& Robinson, C. (1995). Marketing for Tourism. London: Longman Group Limited.

Kotler, P. (1993). Manajemen Pemasaran, Analisis Perencanaan Implementasi dan Penegendalian. Surabaya: Penerbit Erlangga.

Kusmayadi, S. E. (2000). Metodologi Penelitian dalam Bidang Pariwisata. Jakarta: Gramedia Pustaka Utama.

Manessa, MDM. (2008). Kajian Morfologi Karst Untuk Geokonservasi dan Pengembangan Wisata Alam di Kawasan Eko-Karst Gunungsewu. Skripsi, Yogyakarta: Fakultas Geografi Universitas Gadjah Mada.

Mill, R.C., Morrison, A.M. (1985). The Tourism System an Introductory Text. New Jersey: Prentice-Hall Inc.

Natzir, M. (1983). Metodologi Penelitian. Jakarta: Ghalia Indonesia.

Pearce, D.G. (1981). Tourist Development. London: Longman.

Pitana, I.G., dan Gayatri, P.G. (2005). Sosiologi Pariwisata. Yogyakarta: Andi Offets.

Plog, S.C. (1991). Leisure Travel: Making it a Growth Market Again. Canada: JohnWiley \& Sons, Inc..

Sujali (1989). Geografi Pariwisata dan Kepariwisataan. Yogyakarta: Fakultas Geografi UGM. 
Wahab, S. (1992). Pemasaran Pariwisata. Jakarta: Pradnya Paramita.

Weiler, B and Hall, CM. (1992). Special Interest Tourism. London: Belhaven Press.

Yazid (1999). Pemasaran Jasa-Konsep dan Implementasi. Yogyakarta: Ekonisia Fakultas Ekonomi UII
Yoeti , O.A. (1997). Perencanaan dan Pengembangan Pariwisata. Jakarta: PT. Pradnya Paramita.

Yoeti , O.A. (2003). Tour and Travel Marketing. Jakarta: PT. Pradnya Paramita.

Zeitaml, VA., Bitner, MJ. (1996). Services Marketing. London: McGraw-Hill. 